\title{
Implementation of Innovative Learning Material to Improve Students Competence on Chemistry
}

\author{
Marudut Sinaga ${ }^{1}$, Manihar Situmorang $^{2, \star}$, Wesly Hutabarat ${ }^{2}$ \\ ${ }^{1}$ Chemistry Education, Graduate Study Program (Program Pascasarjana), Universitas Negeri Medan, Medan, North Sumatera, \\ INDONESIA. \\ ${ }^{2}$ Department of Chemistry, Faculty of Mathematics and Natural Sciences, Universitas Negeri Medan, Medan, North Sumatera, \\ INDONESIA.
}

\begin{abstract}
Background: Improving students competence to provide appropriate knowledge and skills to deal with professional works becomes a challange in education nowdays. Objectives: This research is aimed to develop and implement an inovative learning material to be used as learning media in the teaching and learning activities to improve students' competence on chemistry. Materials and Methods: The procedures consist of the development and standardization of an innovative learning material with tasks instructions, preparation of research instruments of questionnaire and evaluation tests and implementation of an innovative learning material for teaching and learning activities in the class. Relevant contextual examples, laboratory works, students' activities, media and multimedia and hyperlink to trustworthy websites were integrated into a set of chemistry material to achieve innovative learning material. The instruction for students tasks was also included into the learning package to guide the students to achieve learning goal. Results and Conclusion: Set of learning package has been implemented as learning media in the experimental class on the teaching of chemistry. Compared to control class that used the existing textbook, students' performance in the experimental class was higher than that in control class. An innovative leaning package was discovered to be effective to guide the students to learn chemistry independently. The learning facilities integrated in the learning material help the students to understand chemistry concepts easily. The students enthusiastic to learn chemistry and familiar to use scientific documents to complete the given tasks, as well as having improved ability to write and organize their assignments. Innovative learning material has transformed the chemistry teaching and learning practice from lecturer oriented to students oriented.
\end{abstract}

Key words: Innovative learning material, Multitasks instruction, General Chemistry, Stoichiometry topics, Active learning.

\section{INTRODUCTION}

The development of innovative learning material to be used in the teaching and learning activities is very important as a strategy to improve the student's performance and competence. Innovation in the teaching and learning activities is needed to motivate the students to acquire efficient and effective study, learning and professional skills. ${ }^{1}$ Innovation in education has also been proven to be effective to improve learning activities, to facilitate the development of students' cognitive and to provide enjoyable learning environment. ${ }^{2}$ Learning innovation using technology such as web-based approach and Massive Open Online Courses (MOOCs) can enhance and facilitate student learning process from traditional classroom to studentcentered learning. ${ }^{3-5}$ Innovation in teaching science can be performed through teaching and learning method, strategy and models, modification of laboratory experiment, integration of learning media and multimedia and the development of learning material. ${ }^{6-8}$ Innovation in Chemistry learning material is
Submission Date: 28-03-2018; Revision Date: 14-08-2018; Accepted Date: 23-10-2018

DOI: 10.5530/ijper.53.1.5 Correspondence: Prof. Manihar Situmorang, Department of Chemistry, Faculty of Mathematics and Natural Sciences, Universitas Negeri Medan, Jl. Willem Iskandar, Psr V Medan Estate, Medan, North Sumatera, INDONESIA. Phone: (+62)-61-6625970 E-mail: msitumorang@ unimed.ac.id

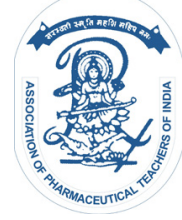

www.ijper.org 
compulsory to obtain good quality learning material that can be used to assist the students in the learning process and to enable them to understand the subject easily.

The development of innovative learning material is considered as an effort to improve the quality of learning activities, as such development is believed to be able to motivate the students to learn and it can be done in the e-book format and interactive multimedia module. ${ }^{10} \mathrm{It}$ is evident that innovation in the teaching and learning materials is effective to improve students' achievement in Chemistry. 'The implementation of contextual learning is also a good strategy to bring the theory into practice of real life. ${ }^{11}$ Standard chemistry learning materials with contextual learning is important to help students understand chemistry concepts and to avoid misunderstanding and misconception on specific chemistry notion. Systematic presentation can facilitate the learners to achieve their competencies. ${ }^{12} \mathrm{~A}$ complete and systematic set of Chemistry learning materials can be provided in the format of books, modules and e-book to facilitate the students to learn Chemistry based on their need. Chemistry learning material in electronic format provides flexibility to be used in the class or outside the class to improve students achievement on Chemistry. ${ }^{13}$ General Chemistry (hereafter abbreviated to Gen Chem) is a compulsory course for students majoring in Science and Pharmacy education at university level. ${ }^{14}$ The knowledge obtained from Gen Chem courses become the foundation to study Advanced Chemistry and other science-related subjects. ${ }^{15}$ Several strategies have been applied in teaching chemistry to students, such as cooperative learning, ${ }^{16}$ problem based learning (PBL), ${ }^{17-18}$ inquiry based ${ }^{19-20}$ and the use of internet. ${ }^{21}$ Stoichiometry topic is considered as difficult subject in Gen Chem, as it needs strong background knowledge in Mathematics. Innovation in the learning strategy to study Stoichiometry is needed to make the students easy to understand the concept. An approach by using stoogiometry, known as Moe's Mall strategy, has been introduced to help learners understand the mole concept of Stoichiometry. ${ }^{22}$ The use of mole ratio flow chart on the teaching of calculation Stoichiometry ${ }^{23-24}$ and with the help of CheMentor software ${ }^{25}$ have been reported to be significant.

The development of innovative chemistry learning material for teaching of Stoichiometry is very important to help the students in their learning process to meet their learning competence in chemistry. Innovative and interactive chemistry learning materials which are in line with the current technology have become compulsory to facilitate the students to learn chemistry based on students' development. Good learning material will also guide the students to learn chemistry effectively and maximize students learning potential. The learning material would help the students to understand chemistry concept clearly, to avoid misunderstanding and misconception on specific chemistry terms and to generate student's motivation to improve their learning study. The aims of this study are to develop an innovative learning material and to demonstrate the impact of an inovative learning material to improve students' performance on the teaching of chemistry. The strategy was made to develop standard chemistry learning material combined with the task instructions for Stoichiometry topic to be used as a learning media in the learning activities to guide the students for active learning to study of General Chemistry.

\section{MATERIALS AND METHODS \\ Population and Sample}

The study was conducted at Universitas Negeri Medan, academic year 2016/2017. The research was carried out with the involvement of 786 students enrolled in the first year of General Chemistry course. The samples were purposively selected from four Departments (Mathematics, Chemistry, Biology and Physics) and each one of them was devided into two groups, named as experimental class and control class. The distribution of selected samples was presented in Table 1. The sample in each group was made homogenous by rejecting outlier samples based on student ability to solve chemistry problems in the pretest followed the procedures explained in the previous study., ${ }^{9,26}$ Samples were all treated equally, but only limited to 30 students per class were included in the data analysis.

\section{Research Procedures}

The reseach procedures consist of the development of innovative learning material for Stoichiometry topic, the preparation of learning instructions for tasks, of standard questionnaire, of evaluation tests with a marking system and the teaching and learning activities in the class with different treatment conditions. The overview of research procedures is summarized in Figure 1.

\section{The Development of Innovative Learning Material}

An innovative learning materials for chemistry was developed by enriching the material of Stoichiometry topic to meet the competence required of studentsas stipulated in curriculum at Universitas Negeri Medan. ${ }^{27}$ The innovation of learning material was conducted following the procedures explained in the previous study. ${ }^{9,26}$ A draft of learning material for Stoichiometry topic has firstly been prepared through the integration 
Table 1: Distribution of samples of first year General Chemistry course involved in the study that were sellected from four Department in the Faculty of Mathematics and Natural Science, Universitas Negeri Medan, North

\begin{tabular}{|c|c|c|c|c|c|c|c|c|}
\hline \multirow[t]{2}{*}{ No } & \multirow[t]{2}{*}{ Department } & \multirow{2}{*}{$\begin{array}{c}\text { Total } \\
\text { Student }\end{array}$} & \multirow{2}{*}{$\begin{array}{l}\text { Paralel } \\
\text { Class }\end{array}$} & \multirow{2}{*}{$\begin{array}{l}\text { Sellected } \\
\text { Class }\end{array}$} & \multicolumn{2}{|c|}{ Sample } & \multirow{2}{*}{$\begin{array}{c}\text { Total } \\
\text { Sample }\end{array}$} & \multirow{2}{*}{$\begin{array}{c}\text { Description of Study } \\
\text { Program }\end{array}$} \\
\hline & & & & & Exp. & Ctrl. & & \\
\hline 1 & Mathematics & 297 & 8 & 2 & 30 & 30 & 60 & - Major in Science \\
\hline 2 & Chemistry & 143 & 5 & 2 & 30 & 30 & 60 & - Major in Science \\
\hline 3 & Biology & 228 & 8 & 2 & 30 & 30 & 60 & - Major in Science \\
\hline 4 & Physics & 143 & 4 & 2 & 30 & 30 & 60 & - Major in Science \\
\hline \multicolumn{2}{|r|}{ Total } & 786 & 25 & 6 & 90 & 90 & 180 & \\
\hline
\end{tabular}

*Exp. is students in experimental class treated with a developed innovated chemistry learning material and Ctrl. is students in control class that are given the existing Chemistry textbooks.

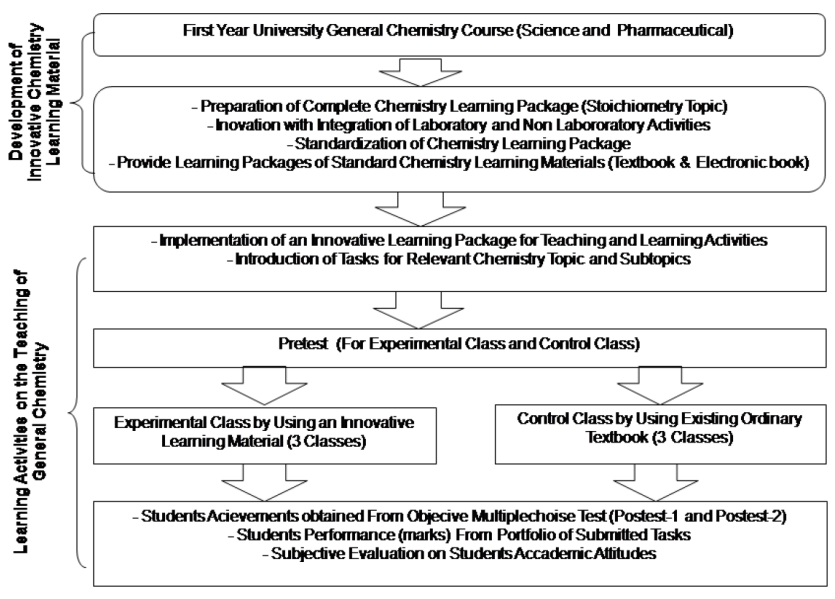

Figure 1: The overview of research procedures in the development of innovative learning material and teaching and learning activities by using of a developed innovative learning material on the teaching of Stoichoiometry topic for first-year chemistry.

of relevant local contents for a contextual example that was suitable for Stoichiometry topic. The innovation comprised the following stages: the integration of relevant laboratory experiment, the preparation of innovative learning media or multimedia and the provision of a hyperlink to selected and trustworthy websites related to Stoichiometry topics. The tasks with specific instruction are equipped in the learning material package. A set of chemistry learning package was then evaluated by experienced chemistry lecturers in teaching General Chemistry for at least three years. Standardization was then caried out to assess the performance of innovative learning material following the standard provided by Indonesian National Education Standards Board (BSNP). A package of innovative Chemistry material was then provided both as printed and electronic format.

\section{Preparation of Multitasks Instruction}

Multitasks and its instruction on Stoichiometry topic have been provided to support teaching and learning activities following the guidelines as stipulated in the university curiculum (Lecture material was given by Professor Syawal Gultom, Rector of Universitas Negeri Medan, 2016). It consists of six compulsory tasks to be completed by students in every subject they learn, including routine task (RT), critical book report (CBR), critical journal/research report (CJR), idea engineering (IE), mini research (MR) and mini project (PR) which is of relevance with the topic being taught. ${ }^{27}$ The instruction for the the tasks has been modified for Stoichiometry topic based on the university guideline. The instruction consisted of specific tasks with learning activities to be completed in the current semester, the format of students' reports for given tasks and the marking system for the submitted tasks. Drills and solving problems were mainly chosen for routine tasks for Stoichiometry topic and they were given to students as separate sheets at the end of the teaching of the chemistry subject. Within the RT, the students were asked to solve chemistry problems and the answers had to be submitted in the following week. Critical book report was prepared by giving a copy on the chapters of General Chemistry textbooks on Stoichiometry topic. The students were asked to analyse the contents of the given topic in the book chapters and submited the report based on the format given in the lecture handout. Critical journal/ research report was designed to analyse one from the five selected articles on Stoichiometry topic. The students were asked to give their opinion on the content of the article following the given instruction and submit their report via email. Idea engineering was designed to motivate the students to give their idea related to subject matter they learn on Stoichiometry topic. With the IR task, the students were free to express their ideas on the application of Stoichiometry topic and the report was submitted a month from the Stoichiometry time table. The task on mini research was carried out to do investigation in the laboratory. The students were divided in 
groups and they were asked to do a simple experiment. Sets of mini research and the procedures on Stoichiometry topic were included in the learning material and were also given as separate handouts. The students were then asked to choose one experiment from the available topics to be completed in the laboratory. The report was asked to be submitted as a personal report. The last task was designed as project based learning (PBL) on specific Stoichiometry topic. The students were provided with the list of web links on PBL containing Chemistry topics related to Stoichiometry. They were given freedom to choose partners in a group to complete the project but the result had to be submitted as a personal report. The schedule to submit every task and the marking system for submitted assignments were included in the Chemistry learning package as well as the separate lecture notes. Individual mark was obtained from every submitted assignment and the average from all tasks were counted in this report. All instructions for multitasks had been integrated in a developed learning material. Separate instructions were also available for students who were not using innovative learning material.

\section{Preparation of Questionaire}

Standard questionnaire was provided to determine students' opinion on the performance of an innovative learning material based on their experience to the learning package of Stoichiometry topic. Preparation and standardization of questionnaire were carried out following the procedures explained previously. ${ }^{28}$ The questions raised in the questionnaire were based on the parameters given by the BSNP with the required criteria for a standard learning material. Assessment components consisted of questions to reveal the contents, extention, depth, design and language with four options from strong to weak opinions. The questions were also facilitated with open questions to give freedom to respondents to express their opinion on the performance of the developed chemistry learning material. Academic attitudes of every students were also investigated by the Chemistry lecturer. Those were based on subjective assessments from students' involvement in teaching and learning activities and the objective assessment from the submitted reports. There were ten parameters being observed for students academic attitudes, namely: (1) communication ability, (2) honesty, (3) responsibility, (4) collaboration, (5) hard-working, (6) caring, (7) discipline, (8) persistency, (9) self independency and (10) learning initiative. ${ }^{27}$ The marking system has been stated for each of the attitudes, ranging between score 1 to 4 , with criteria starting from strong opinion with positive attitudes of very good (score 4), down to a very low attitude with negative of very poor/bad attitudes (score 1).

\section{Evaluation Test and Marking System}

Students' competence was measured in accordance with the combination of their performances in answering the objective evaluation test at the end of the teaching session and the marking fort folio from the submitted tasks following the instruction given at Universitas Negeri Medan. The evaluation test consists of 20 multiple choise tests with five options to measure students' performance on pretest, postest- 1 and postest- 2 . The problems provided in the tests covered all topics in Stoichimetry topic. The marking system for multiple choise test was prepared as score and it was counted based on the right answers given with penalty for any wrong answers. This was followed by the convertion of the score ranging from 0 to 100. A portfolio with marking indicators was used to assess the submitted tasks. The score for submitted tasks was obtained from the average marks on students' performance from the compulsory submitted six tasks. The marking scale for the task lies between $0-100$ marks. Students' achievement and their academic attitudes were then recorded in their semester academic transcripts.

\section{Teaching and LearningActivities}

An innovative chemistry learning material on Stoichiometry topic has been used in the teaching and learning activities. A short training was given to the lecturers to explain their involvement in the study. The lecturers were given a set of procedures to be followed in the teaching and learning activities when using an innovative chemistry learning material. The participations included selecting target samples from the population based on a given criteria, distributing innovative learning materials and used it as learning media in the class, giving tasks and its marking system, collecting and marking of submitted reports, instructing the students to use the chemistry materials and other resources for self-learning, performing evaluations at the allocated time and recording students' academic attitudes. The lectures were also asked to encourage and motivate students to learn and to maximize their learning potential to study chemistry. An attempt has been tried to homogenize the sample by removing outlier sample and only the sample with relatively similar achievements were included in the future study. Outlier samples, those with very high score, were removed from the population and only 30 students were selected to be included in the class for data analysis. All students involved in the teaching and learning activities were treated equally without 
discrimination, but the data were taken from homogen samples. Preliminary evaluation was performed before the teaching treatment were carried out. Teaching activities were conducted to both experimental class and control class. The students in experimental class were taught by using a package of innovated chemistry learning material and the students in control class were given the existing chemistry textbook. The classes were given the same subject matter following their regular schedules. During teaching and learning activities, the students were asked to maximise their learning potential through selflearning to use learning resources available in the the university. The first evaluation test (postest-1) was carried out after completing all stoichiometric topics. This was followed by the second evaluation test (postest-2) a month after postest- $1 .{ }^{26}$ The due date for submiting all tasks were given in the lecture notes and the penalty was applied for late submission. Students' achievements were obtained from students' ability to solve formative test and their performance from the portfolio of submitted tasks. The marking system to obtain a final mark for students' achievement had been formulated and it was counted from the proportion of the formative test and the multitasks $(65 \%: 35 \%){ }^{27}$ Students' competence ideally had to be counted from their results to complete all subjects on General Chemistry. However, students' achievements reported in this study were only obtained from the learning activities on Stoichiometry topic.

\section{RESULTS AND DISCUSSION}

\section{Innovative Chemistry Learning Material}

The development of an innovative chemistry learning materials for Stoichoiometry has been conducted through the analysis of General Chemistry textbooks to choose and to obtain relevant chemistry subjects to be included in learning materials for first year chemistry students. General Chemistry textbooks from different publishers, available online, were used as a foundation to construct the chemistry topics that met the demands stipulated in the university curriculum. The lists of possible chemistry topics to be included for the first year General Chemistry were then discussed by a teaching team in the Department of Chemistry to provide the list containing the final topic for General Chemistry. The first year of General Chemistry contains three credit points per semester, comprising lecture, laboratory experiments and scientific activities. One credit point is equal to $50 \mathrm{~min}$ for lecture and $60 \mathrm{~min}$ for structured learning and $60 \mathrm{~min}$ for individual learning. ${ }^{27}$ There were 16 chemistry sessions of Gen Chem I in one semester for a total of six chemistry topics, including Stoichiometry topic. The list of Chemistry
Table 2: List of chemistry topics for General Chemistry and the allocation time for completing the topic in the Faculty of Mathematics and Natural Science Universitas Negeri Medan at accademic year 2016/2017.

\begin{tabular}{|c|c|c|}
\hline No & Chemistry Subject & $\begin{array}{c}\text { Alocation Time } \\
\text { (weeks) }\end{array}$ \\
\hline 1 & Stoichiometry & 4 \\
\hline 2 & Atomic Structure & 2 \\
\hline 3 & Periodic System & 1 \\
\hline 4 & $\begin{array}{c}\text { Chemical Bonding and Chemical } \\
\text { Structure }\end{array}$ & 3 \\
\hline 5 & Thermo Chemistry & 3 \\
\hline 6 & Chemical Rate & 3 \\
\hline & Total & 16 \\
\hline
\end{tabular}

topics and the allocation time for each of the topic in one semester is listed in Table 2 .

Innovating the chemistry learning material has been conducted to produce a standard learning material for Stoichiometry. It consisted of four sub-subjects, namely (1) Moles concept and formulas of compound, (2) Chemical reactions and chemical equations, (3) Reaction in aqueous solution and (4) Solution Stoichiometry. The time needed to complete Stoichiometry topic has been alocated four weeks in a semester. Chemistry learning material has been developed as the main learning resources for students. Allocated time for learning activities was distributed for class lecture, laboratory works, tasks completion, drills activities, self learning and evaluation test. The distribution of topics and sub-topics of Stoichiometry and the type of tasks to be completed are listed in Table 3.

A package of chemistry material for Stoichiometry topic has been systematically arranged. The package consisted of introduction, main topics and the exercises. The content of chemistry in the learning material was enriched with contextual learning accompanied with relevant illustrations to support the content, followed with problem examples. Innovation has also been made to chemistry topic through the integration of learning media and multimedia to suport the topic, the integration of relevant laboratory works, the addition of problem examples along with the solutions and the preparation of an evaluation test with the answer keys. A learning material was provided with hyperlinks to relevant websites for future reading and to support the given tasks. Furtermore, the instructions for the tasks were prepared in the learning material to guide the students to complete their assignments. Chemistry learning package was then made into a flipbook to help students to use the electronic material. Short description of innovation 


\begin{tabular}{|c|c|c|c|}
\hline No & Stoichiometry topic & Sub-topic of Stoichiometry & $\begin{array}{l}\text { Tasks } \\
\text { integrated in } \\
\text { the learning } \\
\text { activities }\end{array}$ \\
\hline 1 & $\begin{array}{l}\text { Moles Concept and Formulas of } \\
\text { Compound }\end{array}$ & $\begin{array}{l}\text { 1.1. Defining the Mole } \\
\text { 1.2. Molecular Formulas and Molar Mass } \\
\text { 1.3. Interconverting Moles, Mass and Number of Chemical Entities } \\
\text { 1.4. Percentage of Composition and Formulas of Compounds } \\
\text { 1.5. Determining Empirical Formulas: Elemental Analysis } \\
\text { 1.6. Determining Molecular Formulas }\end{array}$ & RT and CJR \\
\hline 2 & $\begin{array}{l}\text { Chemical Reactions and } \\
\text { Chemical Equations }\end{array}$ & $\begin{array}{l}\text { 2.1. Balancing Chemical Equations } \\
\text { 2.2. Ions and lonic Compounds } \\
\text { 2.3. Names and Formulas of Some lonic Compounds } \\
\text { 2.4. Net lonic equation } \\
\text { 2.5. Stoichiometrically Equivalent Molar Ratios from the Balanced Equation }\end{array}$ & $\mathrm{RT}$ and CBR \\
\hline 3 & Reaction in Aqueous Solution & $\begin{array}{l}\text { 3.1. Fundamentals of Solution Stoichiometry } \\
\text { 3.2. Expressing Concentration in Terms of Molarity } \\
\text { 3.3. Mole-Mass-Number Conversions Involving Solutions } \\
\text { 3.4. Dilution of Molar Solutions }\end{array}$ & $\mathrm{RT}$ and MR \\
\hline 4 & Solution Stoichiometry & $\begin{array}{l}\text { 4.1. Stoichiometry of Chemical Reactions in Solution } \\
\text { 4.2. Amount of Reactant and Product } \\
\text { 4.3. The Limiting Reactant Concept } \\
\text { 4.4. Sequential Reactions } \\
\text { 4.5. Chemical Reactions in Practice: Theoretical, Actual and Percent Yields } \\
\text { 4.6. Determining Percentage of Composition in Mixture Compounds }\end{array}$ & RT, IE and PR \\
\hline
\end{tabular}

$\mathrm{RT}=$ Routine task, CBR = Critical Book Report, $\mathrm{CJR}=$ Crtical Journal $/$ Research Report, IE = Idea engineering, MR = Mini Research and PR = Small Project.

that has been intregrated into chemistry learning materials is summarized in Table 4.

A package of chemistry learning material has also been standardized in terms of the procedures explained previously. ${ }^{26}$ The required parameter comprises the standard for the learning material intended for the first year university students. The performance of the learning material was based on the respondents' opinions, which is summarized in Table 5. The result showed that the learning material has met the standard requirement given by the criteria stipulated in BSNP. Respondents of lecturers and senior students all agreed to the book components in the learning material. They gave positive responses to all questions regarding the developed chemistry learning material, which means that the developed learning material is categorized as very good. The book components in the learning material including content, extention, depth, design and the language are all met the criteria for a standard book. Appreciation and positive comments were obtained from lectures, based on their expertise, stating that the developed chemistry material had met the need for undergraduate students to study Stoichiometry.

\section{Implementation of Innovative Learning Material}

A set of developed learning material was used as a learning media in the teaching of Stoichiometry topic for experimental class while the existing textbook was used in the control class. Before conducting the teaching and learning activities, the students were given pretest to investigate their knowledge on the first year university Stoichiometry. Students' achievement based on the pretest presented in Table 6. Showed that the students involved in the study have similar knowledge on Stoichiometry topic, since they have learned Basic Stoichiometry of High School Chemistry. The students were able to answer basic problems but they found difficult to solve university Stoichiometry topic. Students' achievements in both groups were relatively very low. The average scores in the experimental class and control class were similar (see Table 6). These results revealed that all samples were relatively homogenous and ready to be treated with different teaching and learning activities to study Stoichiometry.

An innovative chemistry learning material was used as a learning media to study Stoichiometry topic. An innovative learning package developed in this study was able to guide the students to learn chemistry. It is argued that contextual examples integrated in the learning material were found to be effective to help the students to study chemistry concept easily. ${ }^{29}$ The students intensively used an inovative learning package in their learning activities. It helped the students to answer questions that are raised in the learning instruction. The contribution of the 


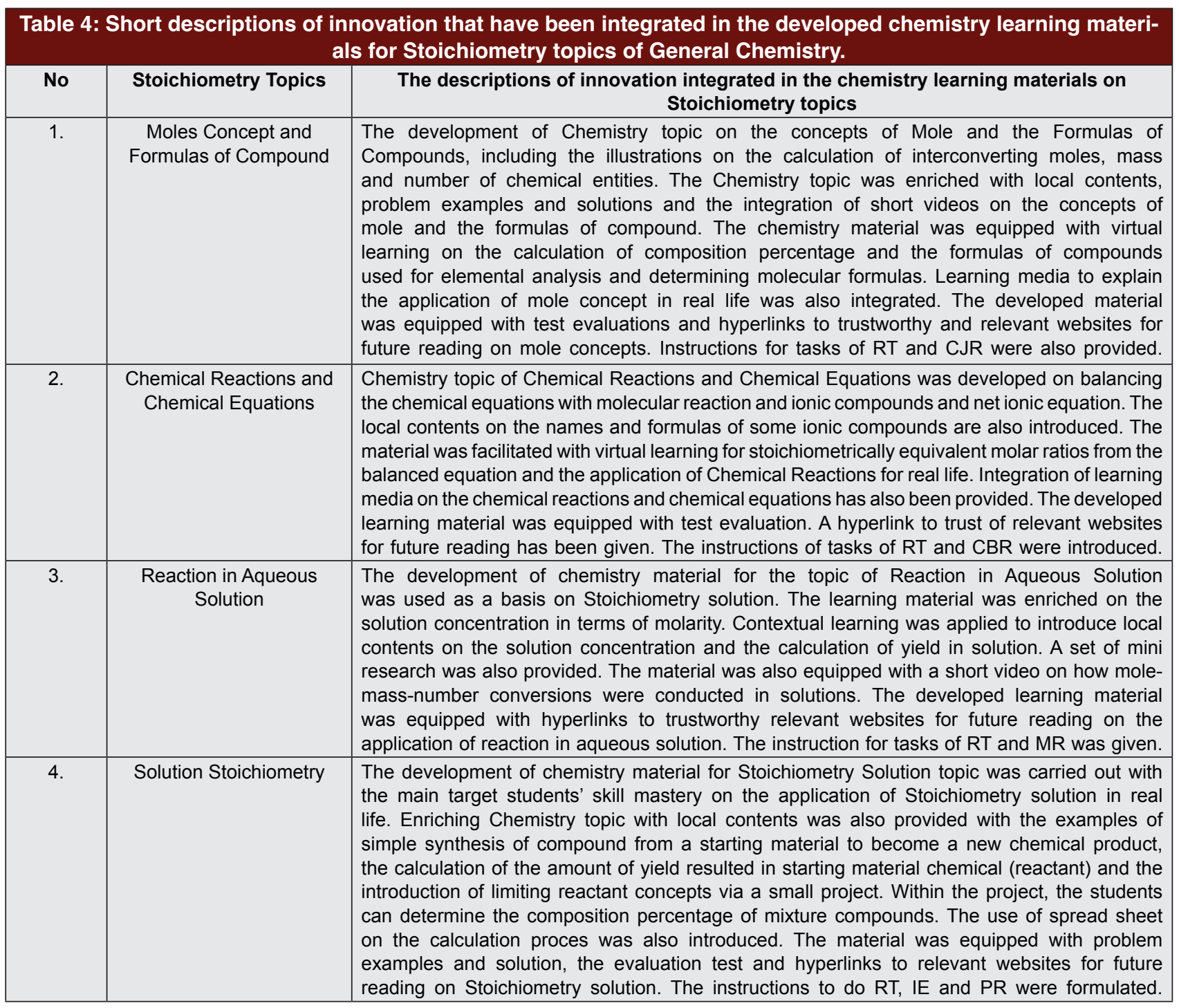

Table 5: Standardization of innovated chemistry learning material based on the respondents opinions. The number is the average value based on the opinion of Chemistry Lecturers $(L)$ as expert judgments and from Senior Chemistry Students (S) that have completed General Chemistry. The number is the average value from

\begin{tabular}{|c|c|c|c|c|}
\hline \multirow{2}{*}{$\begin{array}{c}\text { Book } \\
\text { components }\end{array}$} & \multirow[t]{2}{*}{ Short description of inovative learning material } & \multicolumn{3}{|c|}{ Respondents opinion } \\
\hline & & L & $\mathbf{s}$ & Average \\
\hline \multirow{2}{*}{ Content } & - The completeness of chemistry contents & 3.60 & 3.60 & 3.60 \\
\hline & - The accuracy of the contents & 3.70 & 3.60 & 3.65 \\
\hline \multirow[t]{2}{*}{ Extension } & $\begin{array}{l}\text { - Presented material extension by the integration of local contents, laboratory experiment, } \\
\text { contextual application, learning media and strategy }\end{array}$ & 3.80 & 3.87 & 3.84 \\
\hline & - The chemistry material is clearly derived & 3.80 & 3.70 & 3.75 \\
\hline \multirow[t]{2}{*}{ Depth } & $\begin{array}{l}\text { - The material is presented in good order: introduction, main concepts, problem examples, } \\
\text { drills, quizes and hyperlinks to trustworthy websites }\end{array}$ & 3.65 & 3.72 & 3.69 \\
\hline & - Application concepts with real life & 3.84 & 3.73 & 3.79 \\
\hline \multirow{3}{*}{ Design } & - Suitable between the design layout with the target material & 3.65 & 3.73 & 3.69 \\
\hline & - Presentation of illustration, figures, table and images & 3.65 & 3.66 & 3.66 \\
\hline & - Involving learners for interactive study & 3.85 & 3.76 & 3.81 \\
\hline \multirow{4}{*}{ Language } & - In accordance with the development of learner & 3.65 & 3.52 & 3.59 \\
\hline & $\begin{array}{l}\text { - The chemistry material is easy to read, the language is simple and provides } \\
\text { communicative massage }\end{array}$ & 3.48 & 3.54 & 3.51 \\
\hline & - Straightforward, accuracy on chemistry term and symbol & 3.65 & 3.66 & 3.66 \\
\hline & Average & 3.69 & 3.67 & 3.68 \\
\hline
\end{tabular}


innovative learning material to improve learning competence was investigated. After completing the learning session, the students were given the first evaluation (postest-1) to measure their performance on Stoichiometry topics. Students' achievements obtained from the postest- 1 were summarized in Table 6 . The achievement in the experimental class was higher than that in the control class. A marked answer sheet with the right answers to Chemistry problems were given to students to be used as a feedback and to allow them to evaluate the wrong answers for their future study. The time table for the second evaluation test (postest-2) a month after postest- 1 was also formally announced to make the students have sufficient time to review their weaknesses on Stoichiometry in the first evaluation test. The results from the postest- 2 were summarized in Table 6 . The achievement in the experimental class was higher than that in the control class. The effectiveness of the innovated learning material to improve students' achievement on chemistry was calculated by comparing their achievement in postest- 2 with postest- 1 . The results showed that innovative chemistry learning material was found very effective to improve students' achievement on chemistry.

In addition to the evaluation test, the score from multitasks was also evaluated. The students in the experimental class and the control class completed their tasks on Stoichiometry topic and the submitted tasks were marked based on the university guideline. ${ }^{27}$ The availability of the tasks in the innovative learning package was very helpful for students to master themselves on Stoichiometry topic through self learning. The students were observed very enthusiastic and curious on the subject they learn. The guided tasks has changed the students' learning style from lecturer oriented to students oriented.' The students also became familiar to search new and relevant documents to be used to complete their tasks. Chemistry learning process with guided tasks improved students' ability to write and to organize the assignments. Students' performance based on the marked portfolio obtained from the submitted tasks were recorded and the result in the experimental class was higer than that in the control class (see results in Table 7).

There were four routine tasks completed by the students, which were dealing with problem-solving covering all sub-topics on Stoichiometry. The students tried to use various learning resources to complete their routine tasks. Most of them only relied on using a developed learning package. The students were also involved in completing the tasks, starting from a simple and easy task and to a complex and difficult task, based on the

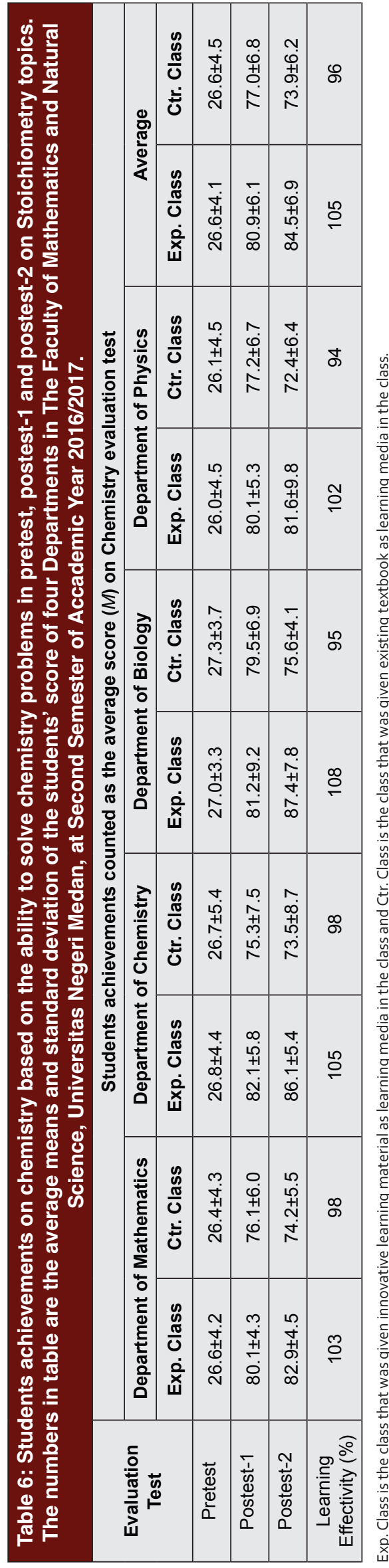




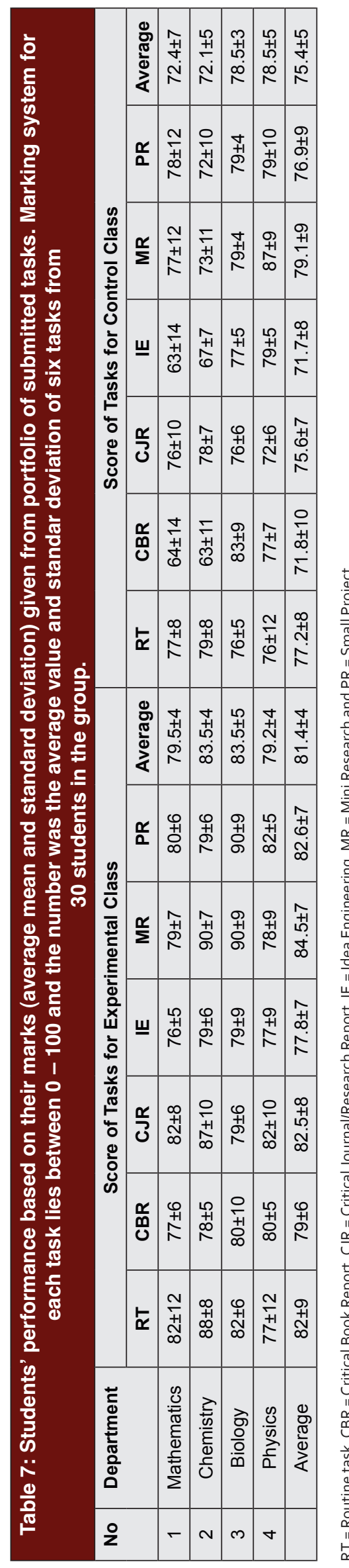

order of sub-subject of Stoichiometry as they progressed in their learning. The average score resulted from the submitted RT was shown in Table 7. The portfolio of the RT showed that students' performance in the experimental class was higher compared witht those in control class. The students in experimental class were interested to use the developed innovative learning material in the teaching and learning activities. The availability of problem examples that were presented in a learning package helped the students to complete their routine tasks. The drills provided at the end of each sub-topic were considered to be sufficient for students to learn the stoichiometric calculation examples. They comprised the subjects of interconverting moles, mass and the number of chemical entities of moles concept and compound formulas, balancing chemical equations of chemical reactions and chemical equations, mole-mass-number convertions involving solutions of reaction in aqueous solution and determining composition percentage in mixture compounds in the Stoichiometry solution.

The instruction to do the critical book report was given in the first lecture, which was mainly to analyse the contents of the Stoichiometry topic from the selected four General Chemistry texbooks. The students were allowed to do CBR in a group of four to five students, but the task had to be submitted as individual report. All students had to submit the CBR report ontime and the average results for CBR score from the experimental class and the control class were summarized in Table 7 . Most students were able to review the textbooks very well folowing the given guideline. The strength and the weakness of Stoichiometry topic in the given book chapters had been analysed. Different opinions were obtained for different Stoichiometry topics in various textbooks. The average results from the experimental class were found higher than that in the control class. The students were able to analyse chemistry topic very well and their opinions were expressed in the reports. Their ability to describe and to analyse the Stoichiometry contents in different book chapters resulted in their ability to write a good report. Many students prepared their CBR review in short reports, comprising 3 to 4 pages. Some of them were long reports consisting of 6 to 10 pages and found to show critical skills with evaluative writing. This strategy made the students become familiar by choosing the right book to study Chemistry. One of the compulsary task that had to be completed in every subject for the first year students was evaluating the content of research report article. The students were given articles on Stoichiometry topics and were asked to analyse the manuscript in a group. The result was submitted as an individual report. The scores for CJR 
are presented in Table 7. The scores for CJR task in the experimental class were higher than those in the control class. Most students had the ability to analyse the given articles clearly. In addition, the contents in the articles were clearly described in very good CJR reports. The students were able to share scientific view and the contributions given by the research reports were described very well. However, some students were found having difficulties to express the CJR reports as they just rewrote the content from the journal abstract or from the conclusion.

To explore the students' views on the Stoichiometry topic, the students were asked to express their ideas on the application of Stoichiometry in the real life as IE task. The students were free to choose their partners to discuss IE task and the report had to be submitted as individual reports on time. The scores for IE report were sumarized in Table 7. Satisfactory results were obtained from the IE tasks, where the average score obtained in the experimental class was higher than that in the control class. Most of the students contributed realistic idea based on their experience in real life related to the Stoichiometry topic. Some students were able to express ideas which are not based on sound reasoning and which are difficult to be implemented nowdays. One student even presented an unexpected scientific view on the topic.

A mini research on the Stoichiometry topic was another compulsory task to be completed by the students in the laboratory. It aimed to improve students' skills in conducting chemical reaction in aqueous solution. It was expected that the students were able to understand the concentration of solution in terms of molarity for stoichiometry calculation and the convertions of MoleMass-Number. Sets of mini research were provided on the mole relationships and the balanced equation, such as the decomposition reaction of sodium bicarbonate (baking soda), as well as a similar mini research that could be completed in two to three hours of laboratory work. Mini research was provided to test students knowledge on stoichiometry principle, factoring labels and the mole concept. The students were asked to collect the data and write standard research reports based on their investigation. This outcome-based research required the students to precisely predict the mass of the solid product. The marking system for the research task was based on the students' ability to write report experiment and how close the students obtained their investigation to a given 'target' sample. Students' achievements for mini research are summarized in Table 7, where students' scores from the experimental class and the control class were provided. In addition to mini research, a project was also introduced as multitasks in the university guideline. The project-based learning was designed to give students insight into how the the Stoichiometry topic could be applied in real-life. The project to be completed was the production of a pain relieving compound of Aspirin. The students were free to design a new project different from the given project. However, the project had to be on the application of Stoichiometry and lecturer approval had to be obtained before the commencement of the project. The students were expected to do the project in groups and the results had to be submitted as individual reports. Most of the project procedures are available in the task instruction and the starting material was given by the laboratory instructor. All students submitted their project reports ontime and the average achiements are shown in Table 7. The average score from the experimental class was higher than that in the control class. ${ }^{30}$ The students were observed and seemed contended to complete the project as it was designed differently compared to the existing laboratory work. The project provided the students with adequate knowledge and skills on Stoichiometry of chemical reactions in solution. It is believed that the experience gained from the project gave profound understanding of the amount of reactant and product, including their comprehension towards the calculation for limiting the reactant concept. The mini research and the project increased their interest on chemistry and on the contribution of chemistry to the real life.

\section{Students' Performance and Academic Attitudes on Chemistry}

Students' performance on chemistry was obtained from the combination of their achievement and attitudes. ${ }^{27}$ Students' achievement was obtained from their ability to answer the evaluation test and the scores obtained from the portfolio of submitted tasks. Students' academic attitudes were also observed during their study time. This observation was mainly based on the lecturer's subjective evaluation on their cumulative academic activities, comprising ten parameters. Some of the parameters include the observation from their learning activities in the class, group discussion, self study, tasks performance and submitted assignments. The average results for students' achievement and academic attitudes were summarized in Table 8 .

The results showed that students' performance in the experimental and control classes were categorized very good. In the experimental class, both students' achievement and their academic attitudes were higher than the students in the control class. A developed learning 
Table 8: First year General Chemistry students' achievement and the academic attitudes in Faculty of

Mathematics and Natural Science, Universitas Negeri Medan, at Academic Year 2016/2017. Students' achievement was obtained from both the evaluation test and the average marks of portfolio of multitasks $(65 \%: 35 \%)$. The academic attitudes are based on Lecturer's subjective evaluation of ten parameters. The criteria are: (4) very good, (3) good, (2) fair and (1) inadequate.

\begin{tabular}{|c|c|c|c|c|c|}
\hline \multirow{2}{*}{ No } & \multirow{2}{*}{ Department } & \multicolumn{2}{|c|}{ Experimental Class } & \multicolumn{2}{c|}{ Control Class } \\
\cline { 3 - 6 } & & Achievement Score & Academic Attitudes & Achievement Score & Academic Attitudes \\
\hline 1 & Mathematics & $81.9 \pm 4$ & $3.45 \pm 0.25$ & $74.9 \pm 7$ & $3.22 \pm 0.26$ \\
\hline 2 & Chemistry & $84.7 \pm 4$ & $3.69 \pm 0.21$ & $74.1 \pm 5$ & $3.15 \pm 0.24$ \\
\hline 3 & Biology & $85.2 \pm 5$ & $3.60 \pm 0.22$ & $77.0 \pm 3$ & $3.45 \pm 0.15$ \\
\hline 4 & Physics & $81.1 \pm 4$ & $3.42 \pm 0.19$ & $74.1 \pm 5$ & $3.35 \pm 0.22$ \\
\hline & Average & $\mathbf{8 3 . 2} \pm 4$ & $\mathbf{3 . 5 4 \pm 0 . 2 2}$ & $\mathbf{7 5 . 0 \pm 5}$ & $3.30 \pm 0.22$ \\
\hline
\end{tabular}

package provided active learning in the teaching and learning activities in the experimental class. Systematic presentation of chemistry subject, accompanied with relevant illustrations presented in a developed learning material was sufficient to help the students to learn chemistry. The availability of contextual example in the learning package made the chemistry topic easy to understand. Learning media and multimedia, short video, illustrations and images that were integrated in the chemistry material helped the students to study chemistry concept efficiently. In addition, the availability of hyperlinks to trusted website in the innovated chemistry materials helped them to explore the relevant chemistry materials for self-learning based on their needs. The developed learning package was suitable for independent learners to improve their competence. The strategy provided in the developed learning materials improved students' interest in learning chemistry and changed the students' learning style from lecturer-orientation to student-oriented learning style. The integrated tasks in the learning package was able to guide learners to complete the assignments and made them familiar by searching relevant topics related to the subject being learned. Students' ability to write and organize their assignments also improved.

\section{DISCUSSION}

The enactment of Indonesian National Qualifications Framework (Kerangka Kualifikasi Nasional Indonesia, KKNI) has prompted the university to implement a competence-based curriculum for every subject taught, including Universitas Negeri Medan. ${ }^{27}$ The current curriculum needs to apply the use of various learning strategies to provide the students with appropriate knowledge and skills of the subject they learn. General Chemistry course is compulsory and one of the basic requirements for all students of science and pharmacy. ${ }^{14}$
Therefore, several strategies were applied for the first year students to make them interested in learning chemistry. ${ }^{31}$ The results obtained in the study suggested that innovation in education has positive impact to the teaching and learning process, resulting in improved students' achievement. Learning innovation conducted in this study had enriched the chemistry contents with contextual examples and the tasks instruction was in line with the university curriculum. The tasks instruction provided in the chemistry learning material are intended to optimize students' potential in learning, as well as to transform the learning process from the conventional lecture-centred to student-centred learning. It is expected that learning activities will equip the students with necessary skills which will be of great importance throughout their education. The implementation of innovative learning material in teaching Stoichiometry guided the learners to maximise their potential to study chemistry. The results were similar with that conducted with other innovations, such as modification of laboratory experiment, ${ }^{32-33}$ integration of learning media and multimedia, ${ }^{6}$ and the development of learning method, ${ }^{9}$ as innovation can bring learning activity more efficient and it was effective to build professional skills. ${ }^{7,34}$ Cooperative learning applied by the students to complete the given tasks has also proved to be a good strategy for teaching science, ${ }^{16}$ while the implementation of inquiry-based learning, ${ }^{19}$ Problem-Based Learning, ${ }^{35}$ mini research ${ }^{36-37}$ through their tasks have become good strategies for chemistry, pharmacy and other relevant sciences teaching.

Stoichiometry topic is one of the challenging subjects to learn in Chemistry. ${ }^{24}$ Various strategies have been done to make Stoichiometry easy to learn. Innovated learning package developed in this study was able to improve students' learning potential in learning chemistry. The first year students found it easy to use the learning 
material and the innovations integrated in the learning package were adequate to guide the students to solve Stoichiometry calculation. ${ }^{38}$ The developed chemistry learning materials with tasks were efficient to improve students' achievement in chemistry. However, some students were still relying on the more conventional learning style, depending on the instruction given by the lecturer. They were probably influenced by their old learning style in the high school. The problem faced in learning chemistry with multitasks was on the limitation of time allocated to complete the tasks. ${ }^{9}$ Some students found it difficult to finish the work punctually. Another problem was found in the contents of the submitted reports. Some reports tended to be similar to other students' reports in the same group. An innovative chemistry learning material developed in this study has become a valuable learning media in the teaching of chemistry. The contribution of developed learning material had been effective to guide the students to learn chemistry. Sytematic presentation of learning material guided the students to maximise their study. Innovation available in the learning package motivated the students to become independent learners.

\section{CONCLUSION}

An innovative, complete and standard chemistry learning material for the first year university students has been developed for chemistry teaching. It consisted of Stoichiometry topics with contextual examples, accompanied with various types of learning media and multimedia and the hyperlinks for self-learning. The tasks instructions were prepared to guide the students to complete the assignments given for relevant sub-topics. A learning package was prepared as printed and electronic bases to assist the students to maximise their potential to study chemistry. The package had been implemented as learning facility to support learning activities in the class or outside the class. The innovation of the learning package made the study become more enjoyable and resulting in improved the students performance in chemistry. Students' achievement in the experimental class was higher than that obtained in the control class. Learning facilities provided in a developed learning package helped the students to understand chemistry concept easily. The task instructions given in the learning package guided the learners to optimize their potential to learn chemistry. The study also showed that innovative learning material helped the students to study chemistry efficiently and improved students' competence. The implementation of innovative learning material had prompted the students to become active learners in and outside the class. The students' mastery of the skills on writing various type of reports was achieved and they were able to construct the knowledge of chemistry topic through given tasks. The instruction given in a learning package motivated the students to work together, to discuss the academic ideas and to solve problems related to the subject they learn.

\section{FINANCIAL DISCLOSURE}

Research grant from Directorate Research and Community Service, Directorate General Strengthen Research and Development, Ministry of Research, Technology and Higher Education Republic of Indonesia, Financial Year 2017, Under Project Penelitian Produk Terapan, Contract No. 045A/UN33.8/LL/2017.

\section{ACKNOWLEGMENT}

The help from Nora Susanti, Jamalum Purba, Freddy Tua Panggabean, Lisnawaty Simatupang, Ratna Sari Dewi, Bajoka Nainggolan, Marham Sitorus, Jasmidi and Agus Kembaren, Lecturer in The Departement of Chemistry, Faculty of Mathematics and Natural Sciences, Universitas Negeri Medan for their involpment in the study are also gratefully acknowledged. The English editing process provided by Isli Iriani Pane from the Language Centre of Universitas Negeri Medan is also acknowledged.

\section{CONFLICT OF INTEREST}

Authors declared that there is no conflicts of interest to disclose with this project work.

\section{ABBREVIATIONS}

MOOCs: Massive Open Online Courses; Gen Chem: General Chemistry; PBL: Problem Based Learning; RT: Routine Task; CBR: Critical Book Report; CJR: Critical Journal/Research Report; IE: Idea Engineering; MR: Mini Research; PR: Small Project; BSNP: Badan Standar Nasional Pendidikan (Indonesian National Education Standards Board); KKNI: Kerangka Kualifikasi Nasional Indonesia (Indonesian National Qualifications Framework).

\section{REFERENCES}

1. Almuqdadi A, Yousef AM, Masoud Z, Majdalawi K, Al-hadeed H, Kalabani R. An Innovative Teaching Strategy for the Outpatient Clerkship Program at Jordan University Hospital A Comprehensive Approach to Faculty Development Program. Indian Journal of Pharmaceutical Education and Research. 2016;50(2):215-24. 
2. Lu TN, Cowie B, Jones A. Senior High School Student Biology Learning in Interactive Teaching. Res Sci Educ. 2010;40(2):267-89.

3. Dagienè V, Gudonienè D. The Innovative Methods for Massive Open Online Course Design. Baltic J Modern Computing. 2015;3(3):205-13.

4. Kraemer A, Ahn S, Hilman S, Fei F. Innovative Learning Modules for Language in Context: MIMEA. CALICO Journal. 2009;27(1):187-204.

5. Bermingham C, Mahdi AE. An innovative web-based approach for study skills development in higher education. International Journal of Web Information Systems. 2007;3(3):212-30.

6. Noor MM, llias K. Practice Teaching and Learning Using Interactive Multimedia Innovation For Non-Optional Teachers Teaching In Music Educations. Academic Research International. 2013;4(2):338-46.

7. Maaß K, Artigue M. Implementation of inquiry-based learning in day-to-day teaching: a synthesis. ZDM Mathematics Education. 2013;45(6):779-95.

8. Situmorang M, Sinaga M, Tobing AML, Sitorus CJ, Tarigan DA. Teaching Innovation in the Laboratory to Increase Student's Achievement in chemistry. Jurnal Penelitian Bidang Pendidikan. 2010;17(1):7-14.

9. Situmorang $M$, Sinaga M, Purba J, Daulay SI, Simorangkir M, Sitorus M, et al. Implementation of Innovative Chemistry Learning Material With Guided Tasks to Improve Students' Competence. Journal of Baltic Science Education. 2018;17(4):535-50.

10. Lee PC, Lin CT, Kang $\mathrm{HH}$. The influence of open innovative teaching approach toward student satisfaction: a case of Si-Men Primary School. Qual Quant. 2016;50(2):491-507.

11. Sung HY, Hwang GJ, Chang HS. An Integrated Contextual and Web-based Issue Quest Approach to Improving Students' Learning Achievements, Attitudes and Critical Thinking. Educational Technology and Society. 2015;18(4):299-311.

12. Jippes E, Van-Engelen JML, Brand PLP, Oudkerk M. Competency-based (CanMEDS) residency training programme in radiology: systematic design procedure, curriculum and success factors. Eur Radiol. 2010;20(4):967-77.

13. Situmorang $M$, Sinaga $M$. The Development of Contextual Learning Material to Improve Students Achevement on the Teaching of Redox Reaction. Prosiding Seminar Nasional dan Rapat Tahunan BKS PTN-B bidang MIPA di Universitas Tanjungpura Pontianak. 2015;549-58.

14. Mai CW, Anitha R, Tiong JJL, Lai PK, Pichika MR, Gray Al. Chemistry Content in the Pharmacy Curriculum: Relevance to Develop Pharmacists Fit-to-work in Diverse Pharmacy Profession Sectors. Indian Journal of Pharmaceutical Education and Research. 2015;49(4):240-7.

15. Collins-Webb A, Jeffery KA. Sweeder RD. Understanding the impact of a general chemistry course on students' transition to organic chemistry. Journal of STEM Education. 2016;17(2):26-33.

16. Kogut LS. Using cooperative learning to enhance performance in general chemistry. Journal of Chemical Education. 1997;74(6):720-22.

17. Gu X, Song X, Sun H, Dong M, Li J, Liu G, et al. Teaching Reform of Pharmaceutical Chemistry with PBL Method. Indian Journal of Pharmaceutical Education and Research. 2016;50(4):530-33.

18. Ansari MT, Rahman SA, Badgujar VB, Sami F, Abdullah, MS. Problem Based Learning (PBL): A Novel and Effective Tool of Teaching and Learning. Indian Journal of Pharmaceutical Education and Research. 2015;49(4):258-65.

19. Farrell JJ, Moog RS, Spencer JN. A guided inquiry general chemistry course. Journal of Chemical Education. 1999;76(4):570-74.

20. DiBiase WJ, Wagner EP. Aligning General Chemistry Laboratory with Lecture at A Large University. School Science and Mathematics. 2002;102(4):158-71.

21. Liu D, Walter LJ, Brooks DW. Delivering a chemistry course over the Internet. Journal of Chemical Education. 1998;75(1):123-5.
22. Krieger CR. Stoogiometry: A cognitive approach to teaching stoichiometry. Journal of Chemical Education. 1997;74(3):306-9.

23. Ramful A, Naro FB. Proportional reasoning in the learning of chemistry: levels of complexity. Math Ed Res J. 2014;26:25-46.

24. Wagner EP. A Study Comparing the Efficacy of a Mole Ratio Flow Chart to Dimensional Analysis for Teaching Reaction Strategy. School Science and Mathematics. 2001;101(1):10-18.

25. Reid BP. CheMentor Software System/CheMentor: Calculating Chemical Formulae. Journal of Chemical Education. 1997;74(9):1047-9.

26. Situmorang $M$, Sitorus $M$, Hutabarat W, Situmorang $Z$. The Development of Innovative Chemistry Learning Material for Bilingual Senior High School Students in Indonesia. International Educational Studies. 2015;8(10):72-85.

27. UNIMED, Kurikulum Berorientasi Kerangka Kualifikasi Nasional Indonesia (KKNI), [Indonesian National Qualifications Framework Curriculum], Universitas Negeri Medan, Medan, Indonesia. 2016.

28. Situmorang M, Sinaga M, Tarigan DA, Sitorus CJ, Tobing AML. The Effectivity of Innovated Chemistry Learning Methods to Increase Student's Achievement in Teaching of Solubility and Solubility Product. Jurnal Penelitian Bidang Pendidikan. 2011;17(1):29-37.

29. Sinaga M, Situmorang M. Pengembangan Bahan Ajar Berbasis Kontekstual Untuk Meningkatkan Hasil Belajar Mahasiswa Pada Pengajaran Reaksi Redoks [The Development of Contextual Learning Material to Improve Students Achevementon the Teaching of Redox Reaction]. Prosiding Seminar Nasional dan Rapat Tahunan BKS PTN-B bidang MIPA di Universitas Tanjungpura Pontianak. 2015;549-58.

30. Alrefaie Z, Eldeek B, Ayuob N. Effect of integrating research skills with basic sciences in an interdisciplinary integrated endocrine module on students' satisfaction and performance. Indian Journal of Pharmaceutical Education and Research. 2017;51(1):14-9.

31. Herdeiro MT, Teixeira RA, Ferreira M, Cruze SD, OAB, Fardilha M. Multimethod Active Learning Approach: improving the educational experience in Pharmaceutical Drug Development. Journal of Pharmaceutical Education and Research. 2014;48(3):16-25.

32. Gooding JJ, Yang WR, Situmorang M. Bioanalytical Experiments for the UndergraduateLaboratory: Monitoring Glucose in Sport Drinks. Journal of Chemical Education. 2001;78(20):788-90.

33. Situmorang $M$, Lee MTB, Witzeman K, Heineman WR. Liquid Chromatography withElectrochemical Detection (LC-EC): An Experiment Using 4-Aminophenol. Journal of Chemical Education. 1998;75(8):1035-8.

34. Svetlana S, Ivana T, Tatjana C, Duskana K, Ian B. Evaluation of Competences at the Community Pharmacy Settings. Journal of Pharmaceutical Education and Research. 2014;48(4):22-30.

35. Tian JH, Liu AP, Yang KH, Shen X. The Effectiveness of Problem-Based Learning on Evidence Based Medicine: A Double-Blind Randomized Trial. Journal of Pharmaceutical Education and Research. 2013;47(3):14-8.

36. Deshpande PR, Chandrakar VR, Bhusare K, Lalwani T, Prasanna MNL, Kanhed A, et al. Research Involvement of Pharmacy Faculties in India. Journal of Pharmaceutical Education and Research. 2018;52(1):21-31.

37. Hassali MA, Saleem F, Farooqui M, Khan TM. Scope of Mix-method studies in Pharmacy Practice Research. Journal of Pharmaceutical Education and Research. 2015;49(2):93-8.

38. Situmorang M, Sitorus CJ. The Innovation of Demonstration Method to Increase Student's Achievement in the teaching of solubility Product. Jurnal Penelitian Bidang Pendidikan. 2012;8(1):1-7.

Cite this article: Sinaga M, Situmorang M, Hutabarat W. Implementation of Innovative Learning Material to Improve Students Competence on Chemistry. Indian J of Pharmaceutical Education and Research. 2019;53(1):28-41. 
PICTORIAL ABSTRACT

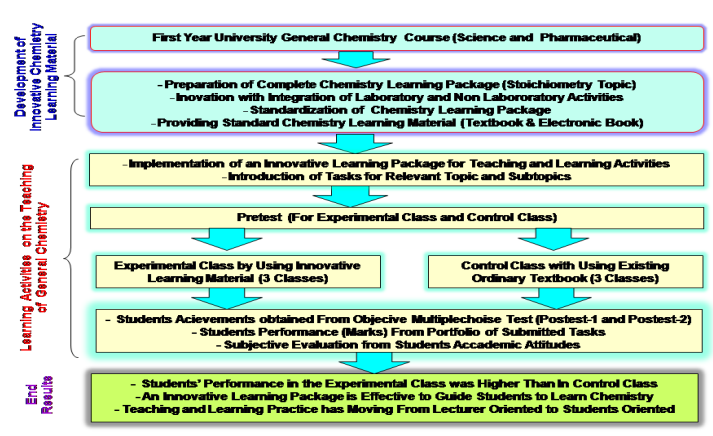

\section{Summary}

An inovative and standard chemistry learning material has been developed to meet the competence curriculum for undergraduate students. The learning development was carried out by enhanching the chemistry topics with integration of relevant contextual examples, laboratory works and multimedia into a chemistry learning package. The developed learning material have been implemented as learning media to improve students' achievement on General Chemistry. Innovative leaning package was effective to guide students to learn stoichiometry, to help the students to understand chemistry concept easily and to bring the students learning style moving from lecturer oriented to students oriented. The students' mastery of the skills on writing various type of reports was achieved and they were able to construct the knowledge of chemistry topic through given tasks.

\section{About Authors}

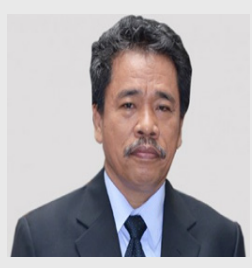

Professor Manihar Situmorang: was born on 4 August 1960. He is a Professor at Department of Chemistry, Faculty of Mathematics and Natural Sciences, Universitas Negeri Medan, Medan, North Sumatera, INDONESIA. He has been teaching for more than 32 years. He has graduated from Dept. of Chemistry Education at Institute of Teacher Training Education Medan, INDONESIA (B.Sc. 1986) and from Dept. of Chemistry, The University of New South Wales (UNSW), Australia (Grad. Diploma 1989, M.Sc, 1992 and Ph.D, 2001). He is currently a Vice Rector on Planning, Collaboration and Communication Affairs at Universitas Negeri Medan, was a Dean in Faculty of Mathematics and Natural Sciences for 8 years, and Head of Research Institute for 4 years. His research interests are Sensor Development, Electroanalysis, Environmental Study and Chemistry Education.

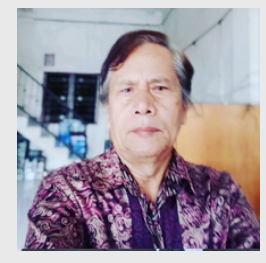

Professor Wesly Hutabarat, was born 20 July 1952, currently a Professor at Department Chemistry Education, Graduate Study Program, Universitas Negeri Medan, Medan, North Sumatera, INDONESIA. He was graduated from Dept. of Chemistry Education at Institute of Teacher Training Education Medan, INDONESIA (B.Sc. 1979), Dept. of Chemistry, SUNY Binghampton, USA (M.Sc. 1988), and Dept. of Education Management, Universitas Negeri Medan, INDONESIA (Ph.D, 2014). He has been teaching for more than 34 years. His research interests are on Chemistry Education, Education Management, and Curriculum Development.

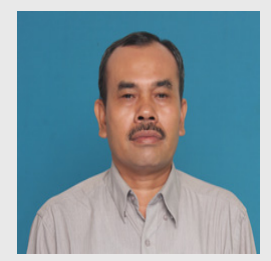

Marudut Sinaga: was born 16 Februari 1963. He is currently a Ph.D student at Chemistry Education, Graduate Study Program, Universitas Negeri Medan, Medan, North Sumatera, INDONESIA. He was graduated from Dept. of Chemistry Education at Institute of Teacher Training Education Medan, INDONESIA (B.Sc. 1987), Dept. of Chemistry, Universitas Gajah Mada (M.Sc. 1996). He hold a position as a Lecturer in The Department of Chemistry Education, Faculty of Mathematics and Natural Sciences, Universitas Negeri Medan since 1996. His research interests are on Analytical Chemistry and Chemistry Education. 